\title{
Parliamentary News
}

Since the General Election in April 1992 Parliamentary business has been fast and furious but singularly devoid of significant events for College notice and attention.

The Queen's speech on 6 May 1992 provided the usual statement of the future legislative programme of the new government and revealed a number of firm priorities of this Conservative government, none of which surprised the reader of the Party's general election manifesto. The 'Asylum' Bill might have been spotted in another era but this deals today with the vexatious matter of those who are (or are not) political refugees.

In previous times the Select Committee system set up in 1979 might have provided another source of potential parliamentary business appropriate to College interests. However the establishment of Select Committees was delayed initially in this Parliamentary session, ostensibly until the Labour Party Shadow Cabinet elections had been concluded. In the event the Select Committees were eventually formed before the results of these elections were known. The most publicised affair of the setting up of Select Committees was the influence of the government whips and the failure of $\mathrm{Mr}$ Nicholas Winterton to be reappointed to the Select Committee on Health and to its Chair. Marion Roe (C Broxbourne) was elected Chair of the Health Committee.

In its programme of work for 1992-93 the Health Committee has a commitment to continue its inquiry into Community Care and has placed the Tomlinson report into London's health service, medical education and research on its programme of work for 1993.

The all-round changes in the membership of the Health Committee have achieved the removal of a number of long-standing critics of government health policy and among them not only those representing the opposition party. It is noteworthy that minority party representation on the Select Committee remains a subject of continuing argument but not of debate.

One new member of the Health Committee has a particular interest in Community Care. David Congdon (C Croydon, North East) has said that his ambition is to be Secretary of State for Health or Education. His previous experience includes a two year spell as Chair of Social Services for Croydon Council.

All members of the Health Committee are pleased no doubt that Gyles Brandreth (C City of Chester) has joined the National Heritage Select Committee since he holds the record for after dinner speaking 12 hours and 30 minutes being his finest effort!

In June 1992 a Lords debate on 'NHS Patients: Privacy and the Media' took place and much attention was paid to the need to provide protection for patients, including the mentally disordered, from intrusion by the media. Lord Carter requested the Department of Health and the Home Office to find a different term than that of mentally disordered, since he believes that all are agreed it is an unfortunate term and highlights only the impossibility of finding a generally acceptable term to encompass the mentally ill, the mentally handicapped (or those with learning disabilities) and those who are drugs and alcohol dependent.

He dealt in similar fashion with the present day tendency for the media to refer to the criminally insane and to the constant reference to Broadmoor Hospital and to a lesser extent Rampton Hospital and Ashworth Hospital as prisons.

Lord Butherfield observed that since 1956 there has been guidance available to the NHS but the problem remains of its enforcement. His view of the 'mentally disordered' group was that they represent a particularly vulnerable group in society and required special protection.

Lord Thomson (of Monifieth) referred in the debate to Lord Donaldson's definition: "the media are an essential foundation of any democracy. However they are so peculiarly vulnerable to the error of confusing the public interest with their own interest". And so say an increasing number of victims of the media's propensity to intrude.

Baroness Cumberlege, Under Secretary of State, Department of Health invoked the authority of the Press Complaints Commission, "Journalists making inquiries at hospitals or similar institutions should identify themselves to a responsible official before entering". She added that there should be no need for the press to enter a hospital furtively. Journalists should be given access after having the courtesy to seek entrance and they have the right to seek permission from the highest authority. There is of course the absolutely inviolate principle that is the individual's right to privacy, in particular in medical matters. Baroness Cumberlege further emphasised the departmental guidance which states that, "Information should not be divulged to the Press without the consent of the patient". In a specialised hospital "no information should be given without the consent of patient and doctor. In the case of well-known 
people, a brief indication of progress can be given but only with the patient's consent".

Consultation on revised guidelines was promised to be wide ranging in the interests of patients, the media and the NHS. A Bill to require newspapers to present news with due accuracy and impartiality; to secure the free dissemination of news and information in the public interest; to prescribe certain professional and ethical standards; to make provision with respect to enforcement, complaint and adjudication; and for commented purposes had its First Reading in the House of Commons on 10 June 1992. The Second Reading is likely to be during January/February 1993.

The Maastricht Treaty has been consuming a great deal of Parliamentary time, yet little if any references appear in public debate or discussions on the pertinent issues of health policy. The Treaty does contain several references to articles on health and notably a specific chapter on health promotion, disease prevention and research which together gives the European Commission (EC) competence in public health for the first time.

The UK had hoped to clarify Maastricht-led public health policy during its Presidency of the EC but ... watch this space.

There are signs that the EC is moving towards concentrating public health matters in Directorate General V (DGV) responsible for Employment, Industrial Relations and Social Affairs. Health is likely to be one portfolio of several for which a Commissioner is likely to be named and who would be consulted on all health proposals. Readers may note that DGV already has responsibility for a Special Programme of support for the reform of mental health care in Greece.

Ring-fencing becomes important again following a statement in the House of Lords on 22 October by Baroness Cumberlege when commenting upon the Secretary of State for Health's announcement of her intention to introduce a ring-fenced special transition grant for Community Care. She explained further that all the new money being transferred to local authorities next year from the social security budget will be ring-fenced. This in itself, she reassured the Lords, would ensure that some of the money will be spent on alcohol and drug services. However the ring-fencing of the total sum of money will give local authorities the flexibility (sic) to decide how much money they wish to spend on those specific services.

The debate in the House of Commons on 22 October on the Health of the Nation provided opportunity for all party support to the entry of mental illness as one of the key tasks of this policy statement. While no strong or strident protagonists emerged to champion the cause of mental illness, there was general accord that its inclusion among the key areas of health policy gave great cause for hope and scope for developments.

We can look forward to more relevant parliamentary business in November and December when Community Care is to be given special attention in the Lords and the Secretary of State for Health will be releasing the review of health and social services for mentally disordered offenders.

JOHN H. HENDERSON

\section{Erratum}

Election and Introduction of Honorary Fellows, Autumn Quarterly Meeting 1992, Psychiatric Bulletin, January 1993, 17, 54-55. Dr Melvin Sabshin. In several places in the citation $\mathrm{Dr}$
Sabshin's first name was incorrectly spelt as Melvyn. Dr Sabshin was appointed Medical Director of the American Psychiatric Association in 1974. 